\title{
Investigation of electro-oxidation of glucose at gold nanoparticles/carbon composites prepared in the presence of halide ions
}

Daina Upskuviené⿱一土,

Dijana Šimkūnaitè,

Jūratė Vaičiūnienè,

Virginija Kepenienè,

Algirdas Selskis,

Loreta Tamašauskaitė-Tamašiūnaitè,

Eugenijus Norkus

State Research Institute

Center for Physical Sciences and Technology,

3 Sauletekio Avenue,

10257 Vilnius, Lithuania
In this study, the carbon powder supported gold nanoparticles composites (AuNPs/C) were prepared via the chemical reduction method by employing sodium citrate or a complex mixture of glucose and ascorbic acid as reducing agents in the presence of small amounts of different halide ions $\left(\mathrm{Cl}^{-}, \mathrm{Br}^{-}, \mathrm{I}^{-}\right)$. The electrocatalytic activity of the synthesized composites was evaluated for the electro-oxidation of glucose in an alkaline medium using cyclic voltammetry, whereas the morphology and composition of composites were characterized using field emission scanning electron microscopy and inductively coupled plasma optical emission spectroscopy.

The electrochemical measurements demonstrate the enhanced electrocatalytic performance of the AuNPs/C composites prepared by the help of different reducing agents coupled with halide ions for the electro-oxidation of glucose as compared to that of composites that were synthesized by the use only of the reducing agents barely. The AuNPs/C composites synthesized with the presence of $\mathrm{KCl}, \mathrm{KBr}$ or $\mathrm{KI}$ additive in the reaction mixture generate the increased glucose electro-oxidation current density values; furthermore, the glucose electro-oxidation potential is shifted to more negative values as compared to those obtained on the synthesized composites without halide additive.

Keywords: gold nanoparticles, halide ions, glucose, electro-oxidation

\section{INTRODUCTION}

Gold is pointed out for its unique and exclusively attractive set of multifunctional physicochemical properties both in macroscopic and microscopic states [1]. Scaling it down to the nanometer size leads to achieving completely novel properties of gold nanoparticles (Au NPs) greatly differing from those of the bulk counterparts [2-4]. Such functional properties of Au NPs have found a wide spectrum

* Corresponding author. Email: daina.upskuviene@ftmc.lt of potential applications ranging from electronics [5], energy [6] and catalysis [7-9] to nano- and bio- medicine [10, 11], sensors [12], optoelectronics [13], food control [14], etc.

The properties of metal NPs are well known to be strongly dependent on their size, shape, crystallinity and surface structure. Variety of shapes, including rods [15, nanowires [16, 17], nanocubes [18, 19], nanoprisms [20], nanoplates [21], nanocages [22], etc., have been developed. In order to control the morphology of the particles, main 'top down' and 'bottom up' approaches for producing AuNPs have been 
introduced $[3,23-26]$. In the first one, the bulk material is degraded (i.e. broken or sliced) with the aim to produce NPs. Meanwhile, in the second approach, conversely, atoms or molecules are assembled to construct NPs. The latter approach is of growing demand since it allows synthesizing homogenous nanostructures that have perfect crystallographic and surface structures of high stability. For generation and characterization of metal NPs, the electrochemical, microwave heating, microemulsion, laser ablation, green synthesis or chemical reduction have been employed [22-26].

Lately, the greatest attention has been focused on the chemical reduction method for generation of noble metal NPs, particularly Au NPs [27, 28], because of an exceptional interest in the use of them as catalysts for the oxidation of alcohol or sugar. This method is based on two major steps, such as the selection of reducing agents in order to reduce $\mathrm{Au}^{3+}$ or $\mathrm{Au}^{+}$ions to $\mathrm{Au}^{\circ}$, and stabilizing agents with the aim to stabilize NPs against aggregation by controlling their growth rate, size and shape. Among the vast majority of reducing agents, such as borohydrides and hydrazine, citric, oxalic or ascorbic acids, sugars (including glucose), polyols, hydrogen peroxide and sulfites have been tested and widely reviewed [26, 27, 29-31]. Meanwhile, stabilizing agents count in such materials as trisodium citrate dihydrate, sulfur or phosphorus ligands, polymers, surfactants (in particular cetyltrimethylammonium bromide (CTAB)), and others [25, 30, 31]. In some cases, the stabilizing agents, for example, like sodium citrate can act as both a weak reducing agent and a capping agent for stabilization of NPs [32]. For now, the most highly utilized chemical synthesis methods are those based on a Turkevich procedure due to an easy and simple preparation process for the obtaining stable NPs with controllable size dimensions [33-36].

The above-mentioned stabilizers coupled with small molecules or ions, such as halides $\left(\mathrm{Cl}^{-}, \mathrm{Br}^{-}\right.$, $\mathrm{I}^{-}$), allow achieving a series of shaped NPs structures with required novel and unique properties including those inherent to anisotropic nanostructures [37-40]. The ability of the direct formation of a certain nanocrystal shape and controlling of their growth highly depends on the halide ions used [38, 41, 42]. For example, bromide is the most suitable halide ion in order to promote the formation of gold nanorods [42-45]. While iodide has been reported to promote the formation of nanoplates and various nanoplate-like shapes 225, 39, 42, 46. In the presence of an excessive bromide, a small amount of iodide produces triangular nanoprisms [33, 42, 43]. Other anions, such as a chloride, have been studied where a chloride ion alone was shown to be unable to produce well-defined anisotropic architectures [42, 43, 45]. Halide ions have a strong tendency to adsorb on metallic surfaces, and thus, to affect the corresponding surface energies. It was found that the adsorption strength of halide ions follows the so-called Hofmeister order: $\mathrm{F}^{-}<\mathrm{Cl}^{-}<\mathrm{Br}^{-}<\mathrm{I}^{-}[38,41]$. The selective use of halides is closely related to their different contribution in changing an electronic conductivity and, therefore, catalytic activity of the generated NPs through the availability of different high index facets. The presence of different high index facets can facilitate or, in contrast, decrease the adsorption or the surface reactions that can occur on one surface, but are not possible on the other [42]. However, it is still difficult to decouple fully the functions of halides from stabilizers in the generation of NPs and an exact operation mechanism remains unclear [39, 47]. Therefore, the precise selection of perfect conditions and reagents, such as metal precursors, solvents, reducing agents, stabilizes, halides, and other additives, is essential, since they determine the properties of NPs. The size and shape of the structured NPs play a key role in their catalytic activity and selectivity [38, 48].

Most of the studies on a correlation between an $\mathrm{Au}$ surface structure and its catalytic activity are concentrated on the electro-oxidation of methanol [49, 50], ethanol [51, 52], or formic acid [53], but only a few of them are focused on the oxidation of glucose [54, 55]. Oxidation of glucose has been of a keen interest, since it can be considered as a renewable fuel in energy conversion systems. Moreover, the oxidation rate of glucose has been shown to depend highly on the electrode material used and on the crystalline orientation of the surface [56]. Nevertheless, Au is well known to be as one of the most suitable material for the oxidation of glucose; however, nanoporous $\mathrm{Au}$ exhibited much better electrocatalytic activity for glucose electrooxidation reaction (GOR) as compared to that of the bulk Au due to its rough surface morphology and the enhanced availability for the adsorption of $\mathrm{OH}^{-}$ion [57]. Furthermore, Au nanorods 
prepared by different means showed an enhancement of the electroactivity towards GOR in the case if (100) facets were present [55]. Shape dependence on the electrocatalytic activity of AuNPs towards GOR has been investigated in Refs. [55, 58, where Au nanocuboids and the spherical Au NPs demonstrated a significantly higher activity than Au nanorods or polyhedrons [55, 58].

In this study, AuNPs that have different shapes were prepared via the chemical reduction method by employing reducing agents, such as sodium citrate or a complex mixture of glucose and ascorbic acid in the presence of small amounts of halide ions $\left(\mathrm{Cl}^{-}, \mathrm{Br}^{-}, \mathrm{I}^{-}\right)$. The synthesized Au NPs were supported on the carbon powder surface by the chemical adsorption approach. The synthesized carbon supported AuNPs composites (labelled as AuNPs/C) were characterized using field-emission scanning electron microscopy (FE-SEM) and inductively coupled plasma optical emission spectroscopy (ICP-OES). The electrocatalytic properties of the synthesized composites were evaluated for the electro-oxidation of glucose in an alkaline medium using cyclic voltammetry (CV).

\section{EXPERIMENTAL}

\section{Chemicals}

$\mathrm{HAuCl}_{4} \cdot 3 \mathrm{H}_{2} \mathrm{O}$ (gold(III) chloride trihydrate, 99.9\%), $\mathrm{Na}_{3} \mathrm{C}_{6} \mathrm{H}_{5} \mathrm{O}_{7} \cdot 2 \mathrm{H}_{2} \mathrm{O}$ (trisodium citrate dehydrate, 99.9\%), $\mathrm{C}_{6} \mathrm{H}_{8} \mathrm{O}_{6}$ (ascorbic acid, 99.0\%), $\mathrm{C}_{6} \mathrm{H}_{12} \mathrm{O}_{6} \cdot \mathrm{H}_{2} \mathrm{O}(\mathrm{D}-(+)$-glucose, 99.5\%) and graphite powder (99.9995\%) were purchased from AlfaAesar and Sigma-Aldrich Suppliers and used as received without further purification. $\mathrm{H}_{2} \mathrm{SO}_{4}(96 \%)$, $\mathrm{NaOH}(98.8 \%)$ and ethanol (96\%) were purchased from Chempur Company. Nafion (5 wt.\%, D521, $1100 \mathrm{EW}$ ) was purchased from Ion Power Inc. Ultra-pure water with a resistivity of $18.2 \mathrm{M} \Omega \mathrm{cm}^{-1}$ was used to prepare all the solutions. All the reagents used were of analytical grade.

\section{Synthesis of AuNPs/C composites}

AuNPs were prepared via the chemical reduction method by employing sodium citrate or a complex mixture of glucose and ascorbic acid as reducing agents in the presence of small amounts of halide ions $\left(\mathrm{Cl}^{-}, \mathrm{Br}^{-}, \mathrm{I}^{-}\right)$. In the first case, AuNPs were deposited on the carbon surface by the chemical adsorption method from a prepared, citrate-stabilized col- loidal solution of AuNPs. In this synthesis, $\mathrm{HAuCl}_{4}$ and $\mathrm{Na}_{3} \mathrm{C}_{6} \mathrm{H}_{5} \mathrm{O}_{7}$ were used as an Au precursor and a reducing agent, respectively. Briefly, $0.3 \mathrm{ml}$ of $0.05 \mathrm{M} \mathrm{HAuCl}_{4}$ was added to $17 \mathrm{ml}$ of ultra-pure water, stirred, mixed with $0.5 \mathrm{ml}$ of $0.01 \mathrm{M}$ solution of $\mathrm{KCl}, \mathrm{KBr}$ or $\mathrm{KI}$ and heated to $90^{\circ} \mathrm{C}$ temperature. Then, $1 \mathrm{ml}$ of $0.1 \mathrm{M} \mathrm{Na}_{3} \mathrm{C}_{6} \mathrm{H}_{5} \mathrm{O}_{7}$ was added to the solutions and stirred at the same temperature until the colour of the solution changed from light blue through pink to cherry red. They were further heated for $15 \mathrm{~min}$ and cooled to room temperature. Then, the resulted $20.5 \mathrm{~mL}$ of citrate-stabilized colloidal $\mathrm{Au}$ NPs solutions, including different halide additives, were mixed with $100 \mathrm{mg}$ of carbon powder at room temperature and stirred for $1 \mathrm{~h}$. After that, the produced precipitates were filtered, washed with an ultra-pure water and dried in a vacuum oven at a temperature of $80^{\circ} \mathrm{C}$ for $2 \mathrm{~h}$. The prepared catalysts were denoted as $\mathrm{AuNP}_{\mathrm{KCl}} / \mathrm{Cl}$, $\mathrm{AuNPs}_{\mathrm{KBr}} / \mathrm{Cl}$ and $\mathrm{AuNPs}_{\mathrm{KI}} / \mathrm{C} 1$.

In the second case, AuNPs on the carbon surface were synthesized using a complex mixture of $0.1 \mathrm{M} \mathrm{C}_{6} \mathrm{H}_{12} \mathrm{O}_{6}$ and $0.05 \mathrm{M} \mathrm{C}_{6} \mathrm{H}_{8} \mathrm{O}_{6}$ as a reducing agent. Herein, $1.5 \mathrm{ml}$ of $0.01 \mathrm{M} \mathrm{HAuCl}_{4}$ solution was added to $30 \mathrm{ml}$ of ultra-pure water, stirred and, similarly as in the first case, mixed with $0.5 \mathrm{ml}$ of $0.01 \mathrm{M}$ of $\mathrm{KCl}, \mathrm{KBr}$ or $\mathrm{KI}$. Then, this solution was treated with $1.0 \mathrm{ml}$ of equally composed $0.1 \mathrm{M}$ $\mathrm{C}_{6} \mathrm{H}_{12} \mathrm{O}_{6}$ and $0.05 \mathrm{M} \mathrm{C}_{6} \mathrm{H}_{8} \mathrm{O}_{6}$ mixture, diluted in $10 \mathrm{ml}$ of ultra-pure water. After the colour changed rapidly from light blue through pink to cherry red, the solutions were poured onto $100 \mathrm{mg}$ of carbon powder at room temperature and stirred for $1 \mathrm{~h}$. The resulting precipitate was filtered, washed with ultra-pure water and dried in a vacuum oven at $80^{\circ} \mathrm{C}$ for $2 \mathrm{~h}$. The synthesized composites were named as $\mathrm{AuNPs}_{\mathrm{KCl}} / \mathrm{C} 2, \mathrm{AuNPs}_{\mathrm{KBr}} / \mathrm{C} 2$ and $\mathrm{AuNPs}_{\mathrm{KI}} / \mathrm{C} 2$.

For comparison, the AuNPs/C composites were prepared in the same manner, except the addition of halide additive. The AuNPs/C composites were prepared using sodium citrate and a complex mixture of glucose and ascorbic acid, and were named as AuNPs/C1 and AuNPs/C2, respectively. In addition, the AuNPs/C2 composites that have different $\mathrm{Au}$ loadings were prepared. For electrochemical measurements, the inks of the obtained composites were prepared according to the following procedure: at first, $10 \mathrm{mg}$ of the synthesized composites were dispersed ultrasonically for $1 \mathrm{~h}$ in a solution 
containing $25 \mu \mathrm{l}$ Nafion and $75 \mu \mathrm{l} \mathrm{H}_{2} \mathrm{O}$ in order to produce a homogeneous slurry. Then, $5 \mu \mathrm{l}$ of the prepared suspension mixture was pipetted onto the polished surface of a glassy carbon electrode (GC) with a geometric area of $0.07 \mathrm{~cm}^{2}$ and dried in a vacuum oven at $80^{\circ} \mathrm{C}$ for $2 \mathrm{~h}$. The Au metal loading in the prepared composites was estimated using an ICP optical emission spectrometer Optima 7000DV (Perkin Elmer). The obtained data are summarized in Table 1 .

Table 1. Au loadings in the composites estimated from ICP-OES measurements

\begin{tabular}{|c|c|c|}
\hline Catalyst & Reducing agent & $\begin{array}{c}\text { Au loading, } \\
\mu \mathrm{g} \mathrm{cm}^{-2}\end{array}$ \\
\hline AuNPs/C $1 / G C$ & \multirow{4}{*}{$\begin{array}{l}\text { Sodium } \\
\text { citrate }\end{array}$} & 67 \\
\hline AuNPs $_{\mathrm{KCl}} / \mathrm{C} 1 / \mathrm{GC}$ & & 177 \\
\hline AuNPs $_{\mathrm{KBr}} / \mathrm{C} 1 / \mathrm{GC}$ & & 176 \\
\hline $\mathrm{AuNPs}_{\mathrm{Kl}} / \mathrm{C} 1 / \mathrm{GC}$ & & 181 \\
\hline AuNPs/C2/GC & \multirow{6}{*}{$\begin{array}{l}\text { Mixture of } \\
\text { glucose and } \\
\text { ascorbic acid }\end{array}$} & 56 \\
\hline AuNPs/C2 ${ }_{95} / \mathrm{GC}$ & & 95 \\
\hline AuNPs/C2 $2_{300} / \mathrm{GC}$ & & 300 \\
\hline AuNPs $_{\mathrm{KCl}} / \mathrm{C} 2 / \mathrm{GC}$ & & 190 \\
\hline AuNPs $_{\mathrm{KBr}} / \mathrm{C} 2 / \mathrm{GC}$ & & 183 \\
\hline $\mathrm{AuNPs}_{\mathrm{Kl}} / \mathrm{C} 2 / \mathrm{GC}$ & & 148 \\
\hline
\end{tabular}

\section{Characterization of composites}

The surface morphology of the prepared composites was examined using a SEM/FIB workstation HeliosNanolab 650 with an energy dispersive X-ray (EDX) spectrometer INCA Energy 350 X-Max 20.

\section{Electrochemical measurements}

Glucose oxidation measurements were performed with a Zennium electrochemical workstation using a conventional three-electrode cell. The differently prepared AuNPs/C/GC composites were employed as a working electrode, a Pt wire was used as the counter electrode and an $\mathrm{Ag} / \mathrm{AgCl} /$ $\mathrm{KCl}(3 \mathrm{M} \mathrm{KCl})$ electrode was used as the reference. Before each measurement, all AuNPs/C/GC catalysts were activated and stabilized in a deaerated $0.5 \mathrm{M} \mathrm{H}_{2} \mathrm{SO}_{4}$ solution at a scan rate of $100 \mathrm{mV} \mathrm{s}^{-1}$ between 0.1 and $1.6 \mathrm{~V}$ until the stable cyclic voltammograms (CVs) were observed. The electrochemically active surface areas (ESAs) of AuNPs in the composites were determined by recording CVs in a deaerated $0.5 \mathrm{M} \mathrm{H}_{2} \mathrm{SO}_{4}$ solution at a scan rate of $50 \mathrm{mV} \mathrm{s}^{-1}$ and calculating the charge under the $\mathrm{Au}$ surface oxide reduction peak $(\mathrm{Q})$ in the CVs according to Eq. (1):

$$
\operatorname{ESA}\left(\mathrm{cm}^{2}\right)=\mathrm{Q}(\mu \mathrm{C}) / 400\left(\mu \mathrm{C} \mathrm{cm}^{-2}\right) .
$$

Here $400 \mu \mathrm{C} \mathrm{cm}^{-2}$ is the charge required for the reduction of the Au oxide monolayer [59].

Then, CVs were recorded on the AuNPs/C/GC catalysts in a background $0.1 \mathrm{M} \mathrm{NaOH}$ solution and that containing $0.1 \mathrm{M}$ glucose at a scan rate of $50 \mathrm{mV} \mathrm{s}^{-1}$ between -0.7 and $0.7 \mathrm{~V}$ at $25^{\circ} \mathrm{C}$ temperature. All solutions were deaerated by argon (Ar) for 15 min prior to measurements. The presented current density values were normalized with respect to the geometric area of composites. The electrode potential was quoted versus the standard hydrogen electrode (SHE).

\section{RESULTS AND DISCUSSION}

The electro-oxidation of glucose was investigated on the carbon supported AuNPs composites prepared by the two-step approach: (i) synthesis of AuNPs via the chemical reduction method by employing two different reducing agents, such as sodium citrate or a complex mixture of glucose and ascorbic acid in the absence and presence of small amounts of halide ions $\left(\mathrm{Cl}^{-}, \mathrm{Br}^{-}, \mathrm{I}^{-}\right)$, and (ii) by the deposition synthesized AuNPs on the carbon surface using the chemical adsorption method. The morphology of AuNPs/C composites was characterized using field emission scanning electron microscopy. Figure 1 shows the FESEM images of the AuNPs/C1 (a) and AuNPs/C2 (b) composites prepared using sodium citrate and the complex mixture of glucose and ascorbic acid as reducing agents, respectively. As evident from the data in Fig. 1a, AuNPs obtained from the citrate-stabilized AuNPs colloidal solution were spherical in shape and distributed in patches all over the surface. The size of AuNPs was found to be ca. $14-15 \mathrm{~nm}$ (Fig. 1a). In the case of the carbon supported AuNPs composite, prepared using the complex mixture of glucose and ascorbic acid as a reducing agent (Fig. 1 b), differently shaped AuNPs of ca. $54 \mathrm{~nm}$ in size and almost uniformly distributed on the carbon surface were deposited. Differently shaped AuNPs of triangular, rectangular, square, spherical or other forms could be detected in the image (Fig. 1 b). 


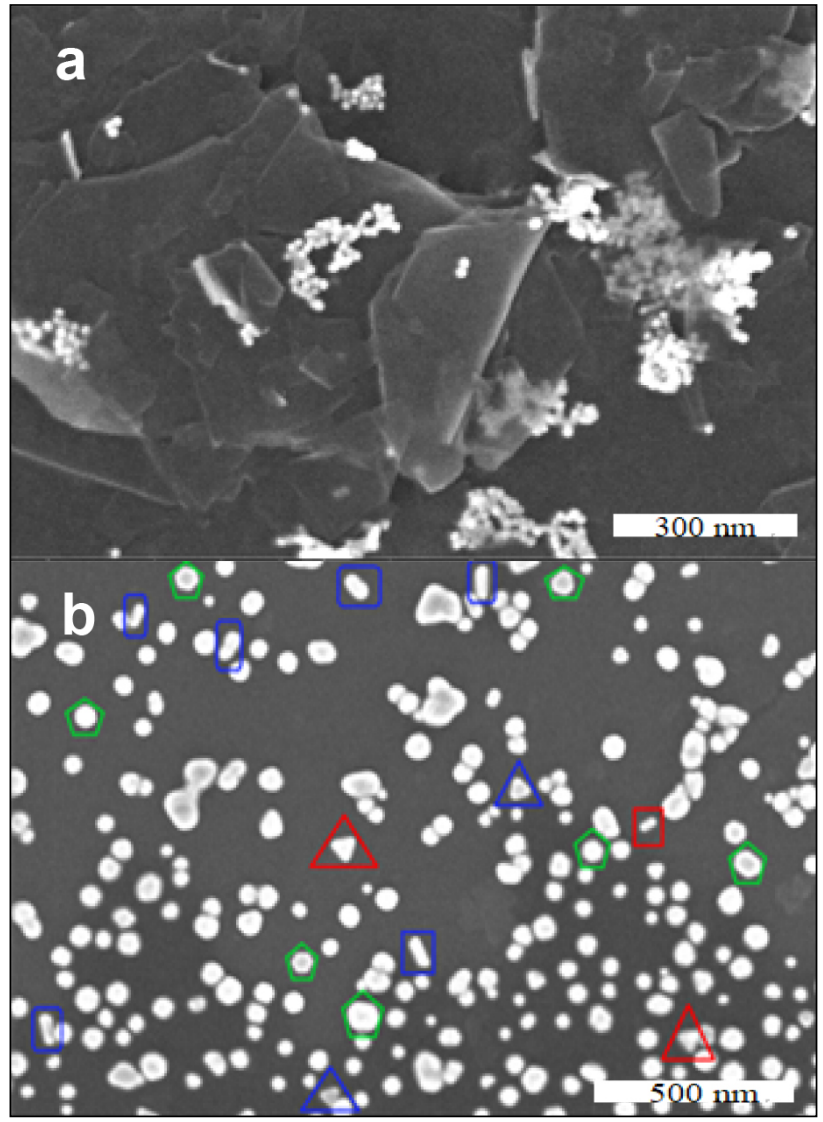

Fig. 1. FESEM images of AuNPs/C1 (a) and AuNPs/C2 (b), prepared via the chemical reduction method by employing sodium citrate or a complex mixture of glucose and ascorbic acid as reducing agents, respectively (coloured online)

The FESEM images of the carbon supported AuNPs prepared via the chemical reduction method in the presence of small amounts of halide ions $\left(\mathrm{Cl}^{-}, \mathrm{Br}^{-}, \mathrm{I}^{-}\right)$by employing sodium citrate or the complex mixture of glucose and ascorbic acid as reducing agents are shown in Fig. 2. In the case when halide ions were used for the synthesis of the composites, the size of AuNPs slightly increased if sodium citrate was used as a reducing agent (Fig. 2a-c), and slightly decreased if the complex mixture of glucose and ascorbic acid was employed as a reducing agent (Fig. 2a'-c'). It equalled to ca. 36 and $32 \mathrm{~nm}$ for AuNPs ${ }_{\mathrm{KBr}} / \mathrm{C} 1$ (a) and $\mathrm{AuNPs}_{\mathrm{KBr}} /$ C2 (a'), to ca. 19 and $45 \mathrm{~nm}$ for $\mathrm{AuNPs}_{\mathrm{KCl}} / \mathrm{C} 1$ (b) and $\mathrm{AuNPs}_{\mathrm{KCl}} / \mathrm{C} 2\left(\mathrm{~b}^{\prime}\right)$, and to ca. 47 and $42 \mathrm{~nm}$ for $\mathrm{AuNPs}_{\mathrm{KI}} / \mathrm{C} 1$ (c) and $\mathrm{AuNPs}_{\mathrm{KI}} / \mathrm{C} 2$ (c'), respectively. It should be mentioned that the special architecture of the aggregated AuNPs that formed a network structure have been developed, then a KI additive and sodium citrate as a reducing agent were used for the preparation of $\mathrm{AuNPs}_{\mathrm{KI}} / \mathrm{C} 1$ catalyst (Fig. $2 \mathrm{c}$ ).
Au loadings in the synthesized composites deposited on a GC electrode were determined by ICP-OES analysis and are shown in Table 1. Notably, the AuNPs/C1/GC and AuNPs/C2/GC catalysts, which were prepared using sodium citrate or the complex mixture of glucose and ascorbic acid as reducing agents, corresponded to 67 and $56 \mu \mathrm{gAu} \mathrm{cm}{ }^{-2}$, respectively. In the case if $\mathrm{Cl}^{-}, \mathrm{Br}^{-}$ and $\mathrm{I}^{-}$ions were used for the preparation of the catalysts, the Au loading significantly increased, regardless of the reducing agent employed. It equalled to 177,176 and $181 \mu \mathrm{gAu} \mathrm{cm}{ }^{-2}$ for $\mathrm{AuNPs}_{\mathrm{KCl}} / \mathrm{Cl} /$ GC, AuNPs KBr $/ \mathrm{C} 1 / \mathrm{GC}$ and $\mathrm{AuNPs}_{\mathrm{KI}} / \mathrm{C} 1 / \mathrm{GC}$; meanwhile, Au loadings of 190, 183 and $148 \mu \mathrm{gAu} \mathrm{cm}{ }^{-2}$ corresponded to AuNPs $\mathrm{KCC}_{\mathrm{KC}} / \mathrm{C} 2 / \mathrm{GC}, \mathrm{AuNP}_{\mathrm{KBr}} / \mathrm{C} 2 /$ $\mathrm{GC}$ and $\mathrm{AuNPs}_{\mathrm{KI}} / \mathrm{C} 2 / \mathrm{GC}$, respectively.

The electrochemically active surface areas of the above-mentioned composites were determined from the CVs recorded in a deaerated $0.5 \mathrm{M} \mathrm{H}_{2} \mathrm{SO}_{4}$ solution at a scan rate of $50 \mathrm{mV} \mathrm{s}^{-1}$ (Fig. 3). Typical $\mathrm{Au}$ oxide formation and its reduction characteristics are observed in the CV profiles of the AuNPs/ C1/GC (line), AuNPs ${ }_{\mathrm{KCl}} / \mathrm{C} 1 / \mathrm{GC}$ (line), AuNPS $\mathrm{KBr}_{\mathrm{Kr}} /$ C1/GC (line) and AuNPs ${ }_{\mathrm{KI}} / \mathrm{C} 1 / \mathrm{GC}$ (line) (Fig. 3a), and AuNPs/C2/GC (line), AuNPs KCl $_{\text {Cl }} / \mathrm{GC}$ (line), $\mathrm{AuNPs}_{\mathrm{KBr}} / \mathrm{C} 2 / \mathrm{GC}$ (line) and AuNPs $\mathrm{s}_{\mathrm{KI}} / \mathrm{C} 2 / \mathrm{GC}$ (line) (Fig. $3 \mathrm{~b}$ ) catalysts. However, it should be noted that in the case of composites prepared using sodium citrate as a reducing agent, the presence of halides resulted in the increase of current values, as compared to that recorded for the catalyst, prepared in the absence of the halide additive (AuNPs/C1/GC). Meanwhile, in the case of composites prepared by employing the complex mixture of glucose and ascorbic acid as a reducing agent, the opposite dependence is observed; the presence of halides resulted in the decrease of current values as compared to those recorded for the catalyst prepared in their absence (AuNPs/C2/GC). The ESAs calculated by a charge of $400 \mu \mathrm{C} \mathrm{cm}{ }^{-2}$ for a monolayer associated with the $\mathrm{Au}$ oxide reduction [49] are summarized in Table 2. They correspond to 0.075 , 0.092, 0.400 and $0.205 \mathrm{~cm}^{2}$ for AuNPs/C1/GC, $\mathrm{AuNPs}_{\mathrm{KCl}} / \mathrm{C} 1 / \mathrm{GC}, \mathrm{AuNPs}_{\mathrm{KBr}} / \mathrm{C} 1 / \mathrm{GC}$ and $\mathrm{AuNPs}_{\mathrm{KI}} /$ C1/GC, respectively, whereas $0.087,0.047,0.033$ and $0.022 \mathrm{~cm}^{2}$ are determined for AuNPs/C2/GC, $\mathrm{AuNPs}_{\mathrm{KCl}} / \mathrm{C} 2 / \mathrm{GC}, \mathrm{AuNPs}_{\mathrm{KBr}} / \mathrm{C} 2 / \mathrm{GC}$ and $\mathrm{AuNPs}_{\mathrm{KI}} /$ $\mathrm{C} 2 / \mathrm{GC}$, respectively. The results show that the ESAs values of the carbon supported AuNPs composites prepared in the presence of $\mathrm{Cl}^{-}, \mathrm{Br}^{-}, \mathrm{I}^{-}$ions and 


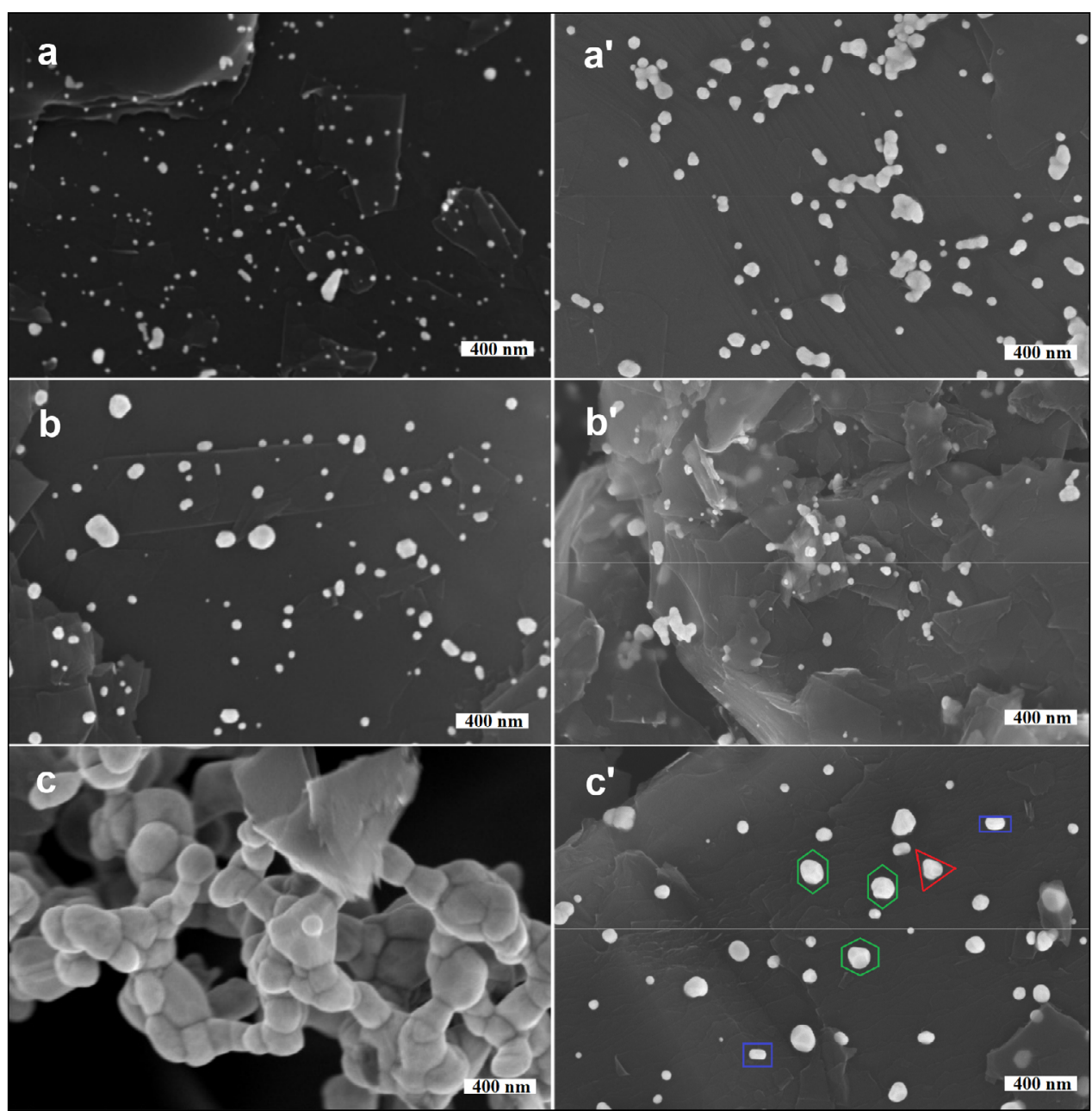

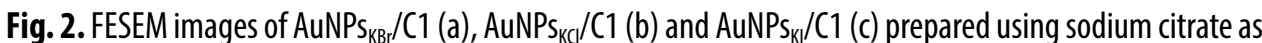

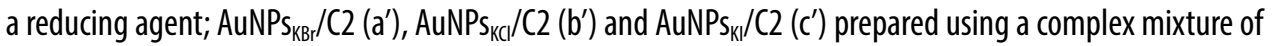
glucose and ascorbic acid as a reducing agent (coloured online)

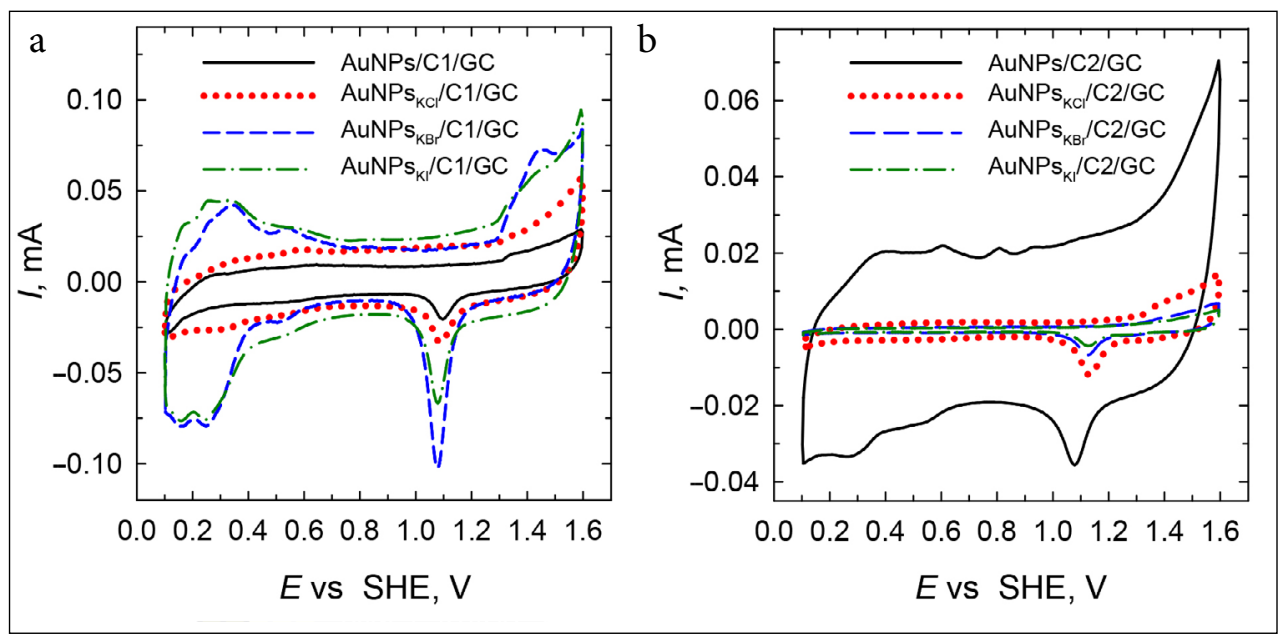

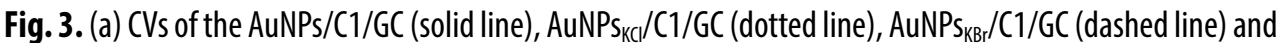
AuNPs $/ / \mathrm{C} 1 / \mathrm{GC}$ (dash-dotted line) composites prepared using sodium citrate as a reducing agent and recorded in $0.5 \mathrm{M} \mathrm{H}_{2} \mathrm{SO}_{4}$ at $50 \mathrm{mV} \mathrm{s}^{-1}$. (b) CVs of AuNPs/C2/GC (solid line), AuNPS $\mathrm{KK}_{\mathrm{KC}} / \mathrm{C} 2 / \mathrm{GC}$ (dotted line), AuNPS $\mathrm{KB}_{\mathrm{KB}} / \mathrm{C} 2 / \mathrm{GC}$ (dashed line) and AuNPs $/ \mathrm{C} 2 / \mathrm{GC}$ (dash-dotted line) composites prepared using a complex mixture of glucose and ascorbic acid as a reducing agent and recorded in the same solution (coloured online) 
Table 2. Electrochemically active areas of the Au surface of the prepared composites determined from $\mathrm{CV}_{s}$ recorded in $0.5 \mathrm{M} \mathrm{H}_{2} \mathrm{SO}_{4}$ at $50 \mathrm{mV} \mathrm{s}^{-2}$

\begin{tabular}{|c|c|}
\hline AuNPs/C1/GC & 0.075 \\
\hline AuNPs $_{\mathrm{KCl}} / \mathrm{C} 1 / \mathrm{GC}$ & 0.092 \\
\hline $\mathrm{AuNPs}_{\mathrm{KBr}} / \mathrm{C} 1 / \mathrm{GC}$ & 0.400 \\
\hline $\mathrm{AuNPs}_{\mathrm{K} /} / \mathrm{C} 1 / \mathrm{GC}$ & 0.205 \\
\hline AuNPs/C2/GC & 0.087 \\
\hline AuNPs $_{\mathrm{KCl}} / \mathrm{C} 2 / \mathrm{GC}$ & 0.047 \\
\hline $\mathrm{AuNPs}_{\mathrm{KBr}} / \mathrm{C} 2 / \mathrm{GC}$ & 0.033 \\
\hline $\mathrm{AuNPs}_{\mathrm{K} /} / \mathrm{C} 2 / \mathrm{GC}$ & 0.022 \\
\hline
\end{tabular}

using sodium citrate as a reducing agent increased and are $1.22,5.33$ and 2.73 , respectively, times higher than those of the AuNPs/C1/GC catalyst. Whereas, the employment of the complex mixture of glucose and ascorbic acid as a reducing agent in the presence of $\mathrm{Cl}^{-}, \mathrm{Br}^{-}$and $\mathrm{I}^{-}$ions, on the contrary, leads to the decrease of ESAs values when compared to those of the AuNPs/C2/GC catalyst, and are 0.54, 0.38 and 0.25 times lower on $\mathrm{AuNPs}_{\mathrm{KCl}} / \mathrm{C} 2 / \mathrm{GC}$, $\mathrm{AuNPs}_{\mathrm{KBr}} / \mathrm{C} 2 / \mathrm{GC}$ and $\mathrm{AuNPs}_{\mathrm{KI}} / \mathrm{C} 2 / \mathrm{GC}$.

At first, the electro-oxidation of glucose was investigated on the AuNPs/C composites prepared without halide additives in the reaction mixture using cyclic voltammetry. Figure 4 shows the stabilized CVs (10th cycles) for the AuNPs/ C1/GC catalyst (a) that has the Au loading of $67 \mu \mathrm{gAu} \mathrm{cm} \mathrm{cm}^{-2}$ and the AuNPs/C2/GC catalysts that have the Au loading of 56 (b), 95 (c) and 300 (d) $\mu \mathrm{gAu} \mathrm{cm} \mathrm{cm}^{-2}$ recorded in a $0.1 \mathrm{M} \mathrm{NaOH}$ solution (dashed lines) and that containing $0.1 \mathrm{M}$ glucose (solid lines) at a scan rate of $50 \mathrm{mV} \mathrm{s}^{-1}$ at $25^{\circ} \mathrm{C}$.

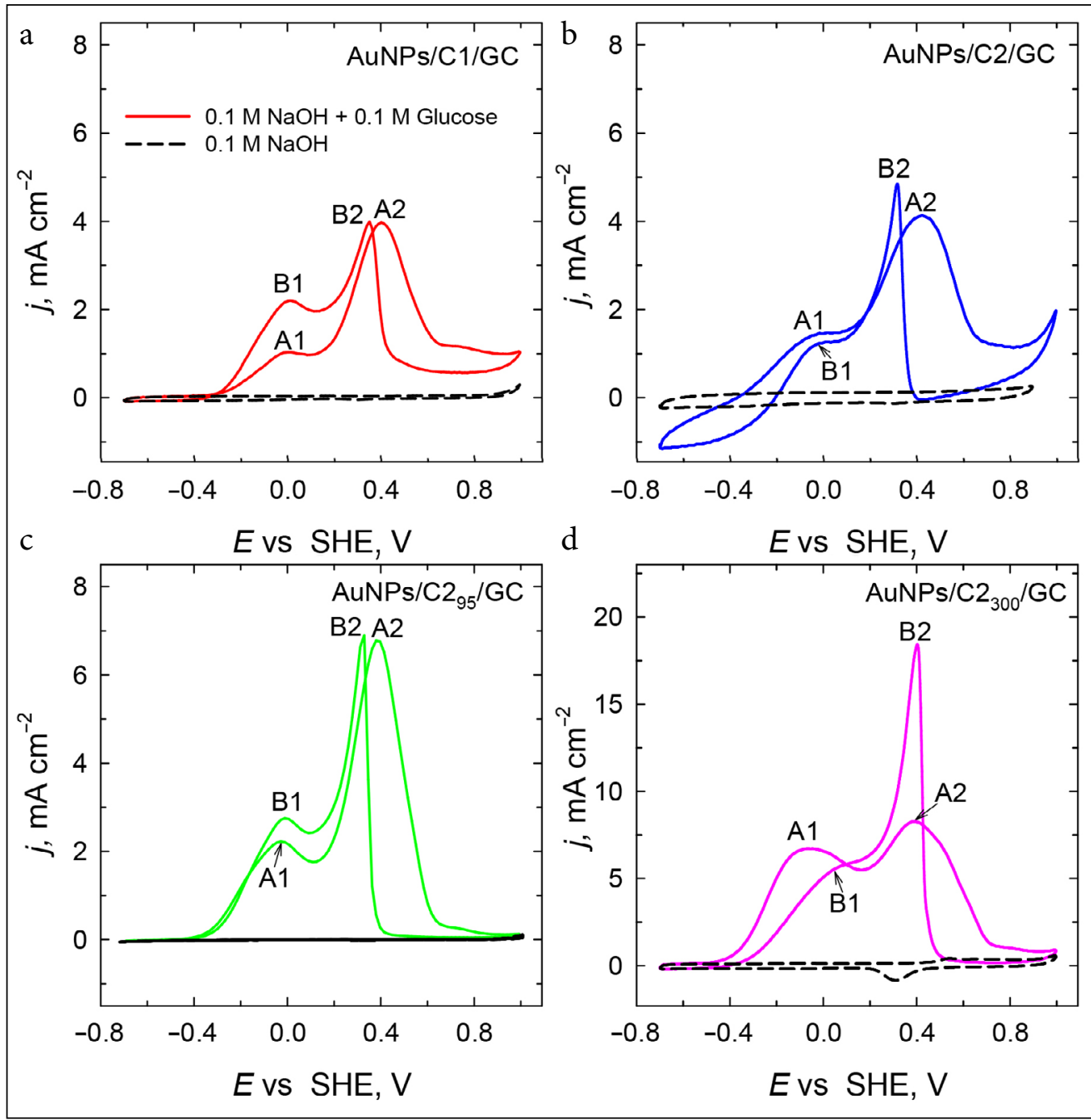

Fig. 4. Stabilized CVs for AuNPs/C1/GC (a), AuNPs/C2/GC (b), AuNPs/C2 $/ \mathrm{GC}(\mathrm{c})$ and $A u N P s / 2_{300} / \mathrm{GC}$ (c) recorded in a $0.1 \mathrm{M} \mathrm{NaOH}$ solution (dashed line) and that containing $0.1 \mathrm{M}$ glucose (solid line) at a scan rate of $50 \mathrm{mV} \mathrm{s}^{-1}$ at $25^{\circ} \mathrm{C}$ (coloured online) 
The addition of glucose into the system results in an apparently changed shape of the CV curves as compared to those obtained in the background $0.1 \mathrm{M} \mathrm{NaOH}$ solution. A significant increase in current densities and the generation of two anodic current peaks A1 and A2 when the electrode potential is scanned to positive values, and another two B1 and B2 during the cathodic potential scan are observed for all the CV curves (Fig. $4 \mathrm{a}-\mathrm{d}$, solid lines), regardless of the reducing agent or even Au loading used. It should be mentioned that the obtained voltammetric data for the investigated catalysts in the presence of $0.1 \mathrm{M}$ glucose, as compared to those presented in Refs. [50, 60-62], show that the recorded CV curves do not undergo radical transformations, moreover, they are similar in shape and coincides well with those observed earlier. Generally, two well-distinguished anodic peaks A1 and A2, one at lower potential values located at ca. $-0.1 \mathrm{~V}$ and another one at more positive potential values at ca. $0.4 \mathrm{~V}$, are attributed to the oxidation of adsorbed glucose and to the further oxidation of intermediate species, generated in the first peak, to gluconate, respectively [54, 60-64]. It is supposed that at first, the glucose molecule is electrochemically adsorbed at the surface of the electrode by the dehydrogenation reaction, and then it is followed by the transformation of the dehydrogenated molecule (i.e. an intermediate generated by anomeric carbon dehydrogenation) to gluconate through the direct oxidation (Eq. (2)). The dehydrogenated glucose molecule could also be oxidized to $\delta$-gluconolactone (Eq. (3)), which is further transformed to gluconate after the reaction with a hydroxide ion $[54,60]$. The chemical reactions involved in the proposed glucose oxidation mechanism at the anode may be briefly presented by the following equations [54, 60]:

$$
\begin{aligned}
& \mathrm{C}_{6} \mathrm{H}_{12} \mathrm{O}_{6}+2 \mathrm{OH}^{-} \rightarrow \mathrm{C}_{6} \mathrm{H}_{11} \mathrm{O}_{7}^{-}+\mathrm{H}_{2} \mathrm{O}+\mathrm{H}^{+}+2 \mathrm{e}^{-}, \\
& \mathrm{C}_{6} \mathrm{H}_{12} \mathrm{O}_{6}+\mathrm{OH}^{-} \rightarrow \mathrm{C}_{6} \mathrm{H}_{10} \mathrm{O}_{6}+\mathrm{H}^{+}+2 \mathrm{e}^{-} .
\end{aligned}
$$

The pronounced peaks $\mathbf{B} 2$ and $\mathbf{B} 1$ may be attributed to the oxidation of intermediate species formed during the oxidation of glucose and to the oxidation of glucose on the renewed gold surface after the gold oxide layer reduction, respectively [60, 61].
It is well known that the formation of catalytically active sites $\mathrm{Au}-\mathrm{OH}_{\mathrm{ads}}$ is the most important factor for GOR [65]. The generation of an oxide precursor in the potential region prior to the gold oxide formation plays a key role in the enhancement of the catalytic activity of $\mathrm{Au}$ in an alkaline medium. On the other hand, the intensity of the oxidation peaks on the Au electrode significantly depends on the presence of specific crystallographic planes on the gold surface [60, 61]. The analysis of the maximum current density values of each process occurring in the potential region of anodic peaks A1 and A2 shows that they differ significantly at the composites that have low Au loadings of 67 and 56 or even $95 \mu \mathrm{gAu} \mathrm{cm}{ }^{-2}$ for the AuNPs/C1/GC and AuNPs/C2/GC or AuNPs/C2 ${ }_{95} / \mathrm{GC}$ catalysts, respectively (Fig. $4 \mathrm{a}-\mathrm{c}$ ). Current maximum values generated for peak $\mathbf{A 2}$ is ca. 3.85 times higher than those of peak A1 for the AuNPs/C1/GC catalyst containing the Au loading of $67 \mu \mathrm{gAu} \mathrm{cm}{ }^{-2}$ (Fig. $4 \mathrm{a}$ ), ca. 2.83 times higher than those of peak $\mathbf{A 1}$ for the AuNPs/C2/GC catalyst containing the Au loading of $56 \mu \mathrm{gAu} \mathrm{cm} \mathrm{cm}^{-2}$ (Fig. $4 \mathrm{~b}$ ), and ca. 3.04 times higher than those of peak A1 catalyst containing the Au loading of $95 \mu \mathrm{gAu} \mathrm{cm}{ }^{-2}$ (Fig. $4 \mathrm{c}$ ). Such relation in the current peak values points to the fact that the gold surface is more active for the oxidation of glucose. Possibly, the availability of $\mathrm{Au}-$ $\mathrm{OH}_{\text {ads }}$ sites is limited for the oxidation of glucose at negative potentials before the potential region of anodic peak A1, resulting in lower current values generated. However, the increase in the Au loading to $300 \mu \mathrm{gAu} \mathrm{cm}{ }^{-2}$ for the AuNPs/C2 $2_{300} / \mathrm{GC}$ catalyst (Fig. 4 4 ), both maximum current density values at peaks $\mathbf{A 1}$ and $\mathbf{A 2}$ increase and become almost of the same magnitude, pointing to the fact that the gold surface becomes almost equally active to the oxidation of both glucose and glucose intermediate species (Fig. $4 \mathrm{~d}$ ).

The electro-oxidation of glucose was also investigated on the AuNPs/C2 ${ }_{95} / \mathrm{GC}$ catalyst containing the Au loading of $95 \mu \mathrm{gAu} \mathrm{cm} \mathrm{cm}^{-2}$ in a $0.1 \mathrm{M} \mathrm{NaOH}$ and $0.1 \mathrm{M}$ glucose solution at various scan rates in the potential window from -0.7 to $1.0 \mathrm{~V}$ (Fig. 5). Figure $5 \mathrm{a}$ presents the positive-potential going scans recorded on the latter catalyst at scan rates from 5 to $100 \mathrm{mV} \mathrm{s}^{-1}$. It is clearly seen that peak current density values $\left(j_{\mathrm{pA} 1}\right.$ and $\left.j_{\mathrm{pA} 2}\right)$ generated under the potential region of both anodic peaks A1 and A2 increase gradually with the increase of the potential scan rate 


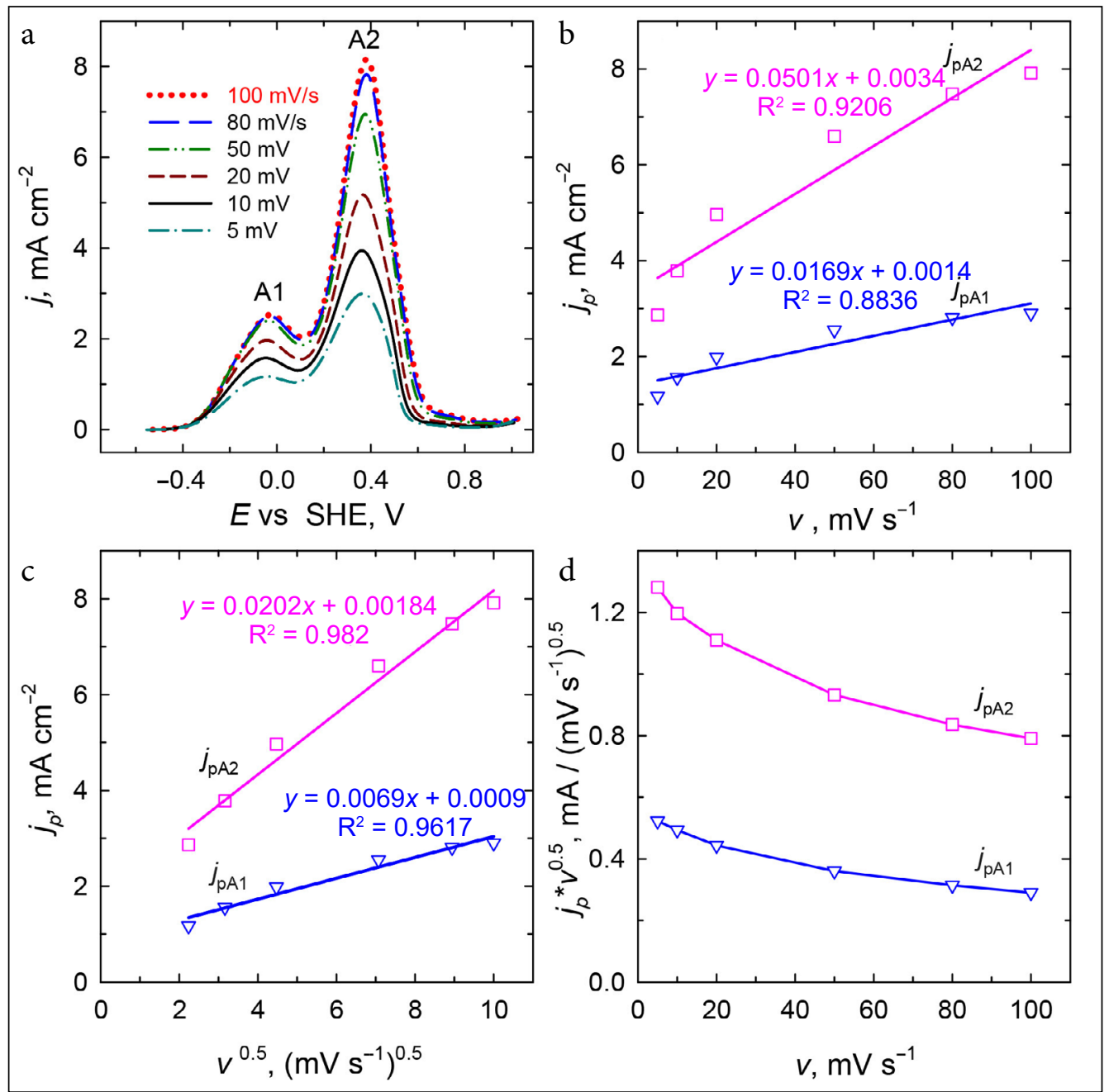

Fig. 5. The positive-potential going anodic scans for AuNPs $/ \mathrm{C}_{95} / \mathrm{GC}$ recorded in a $0.1 \mathrm{M} \mathrm{NaOH}$ and $0.1 \mathrm{M}$ glucose solution at scan rates from 5 to $100 \mathrm{mV} \mathrm{s}^{-1}$ at $25^{\circ} \mathrm{C}$. The fitting plots of peak current densities versus scant rates (b) or versus the square root of scan rates $(c)$ and plots of the scan rate-normalized currents $\left(j_{p} / v^{1 / 2}\right)$ with respect to the scan rate (d) at the anodic potentials of both $\mathrm{A} 1$ and $\mathrm{A} 2$ peaks (coloured online)

values from 5 to $100 \mathrm{mV} \mathrm{s}^{-1}$, whereas the potentials of the anodic peaks $\left(E_{\mathrm{pA} 1}\right.$ and $\left.E_{\mathrm{pA} 2}\right)$ remain almost independent of the scan rate. Moreover, both anodic peak currents $j_{\mathrm{pA} 1}$ and $j_{\mathrm{pA} 2}$ obtained for the electrooxidation of glucose are proportional to the scan rate (Fig. $5 \mathrm{~b}$ ) and to the square root of the scan rate (Fig. 5c). The linear correlation coefficients between $j_{\mathrm{pA} 1}$ and $j_{\mathrm{PA} 2}$ versus a scan rate and a square root of the scan rate are $0.8836,0.9206,0.9617$ and 0.982 , respectively. The latter values for the plots of the anodic peak currents $j_{p}$ versus the square root of the scan rate are higher (Fig. $5 \mathrm{c}$ ) than for the scan rate (Fig. 5b), suggesting that the overall electrooxidation of glucose at this electrode might be controlled by the diffusion of glucose from the solution to the redox sites on the surface. A typical diffusioncontrolled reaction for the reversible process can be confirmed by the Randles-Sevcik equation, and is written as follows:

$$
i_{p}=2.69 \times 10^{5} n^{3 / 2} A(D v)^{0.5} C .
$$

Here $i_{p}$ denotes the value of the peak current (A), $n$ is the number of electrons appearing in a half-reaction of the redox couple, $A$ is the area of the electrode $\left(\mathrm{cm}^{2}\right), C$ denotes the concentration of the analyte $\left.(\mathrm{mol} \mathrm{cm})^{-3}\right), D$ is the diffusion coefficient of the analyte $\left(\mathrm{cm}^{2} \mathrm{~s}^{-1}\right)$, and $v$ is the potential scan rate $\left(\mathrm{V} \mathrm{s}^{-1}\right)$. In general, $n, A, C$ and $D$ are fixed during a typical electrochemical reaction; therefore, $i_{p}$ is proportional to the square root of the scan rate. For the calculations the diffusion coefficient of glucose $6.70 \times 10^{-6} \mathrm{~cm}^{2} \mathrm{~s}^{-1}$ [67] was used. As evident from the data in Fig. $5 \mathrm{~d}$, the plots of the scan rate-nor- 
malized currents $\left(j_{p} / v^{1 / 2}\right)$ with respect to the scan rate exhibit a typical shape of an electrochemicalchemical (EC') catalytic process [66].

The electrochemical behaviour of the composites prepared in the presence of small amounts of halide ions $\left(\mathrm{Cl}^{-}, \mathrm{Br}^{-}, \mathrm{I}^{-}\right)$using sodium citrate or the complex mixture of glucose and ascorbic acid as reducing agents are shown in Fig. 6. CVs are similar in shape as compared to those obtained at AuNPs/C1/GC and AuNPs/C2/GC catalysts as in Fig. 4. The similar anodic current peaks A1, A2 and B1, B2 during anodic and cathodic potential scans, respectively (Fig. 6), characterize them. However, the current density values generated for the anodic peaks A1 and A2

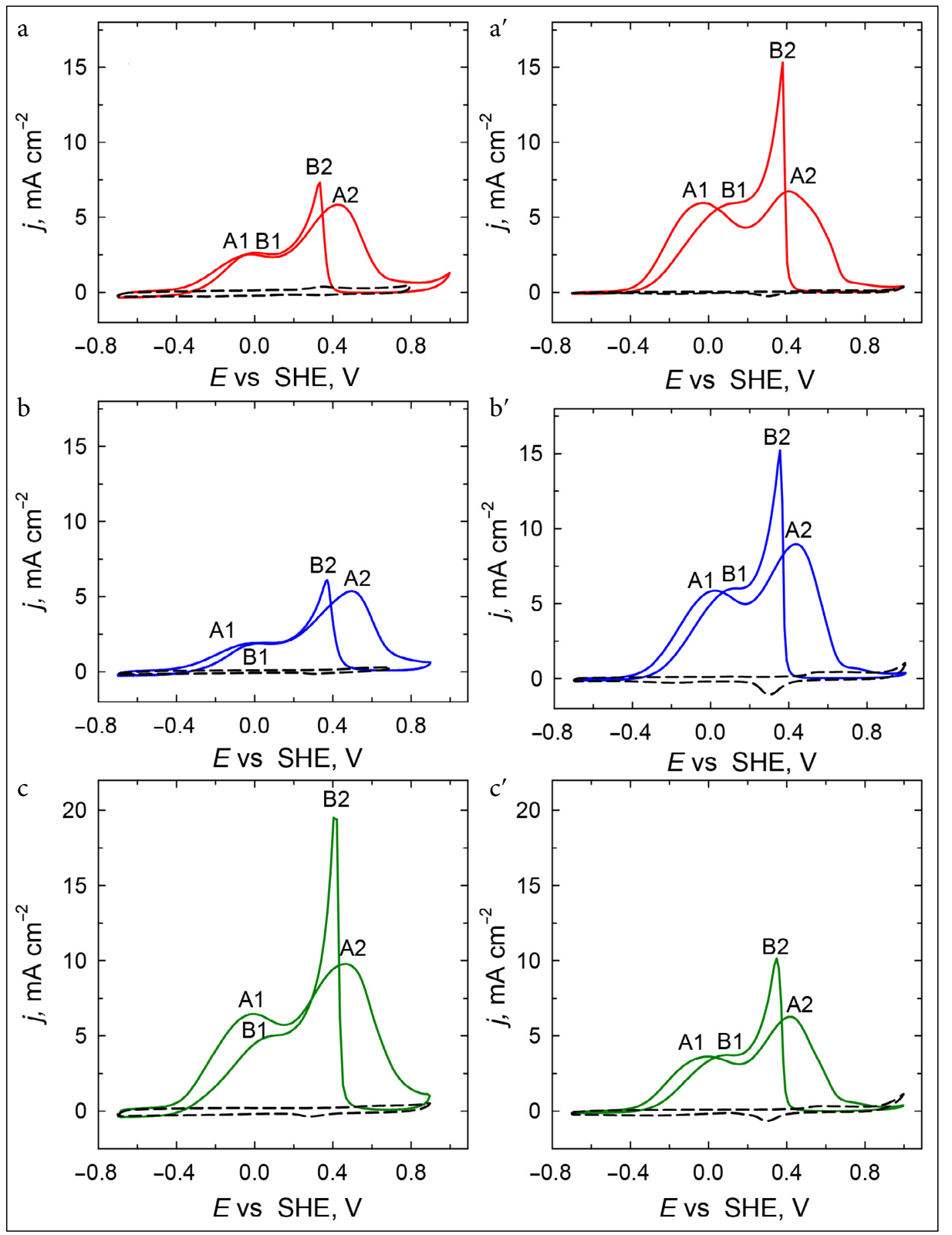

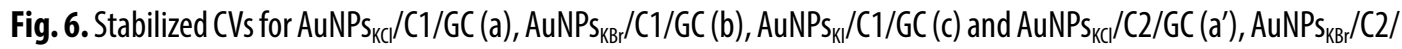
$\mathrm{GC}\left(\mathrm{b}^{\prime}\right)$ and $\mathrm{AuNPS}_{\mathrm{K}} / \mathrm{C} 2 / \mathrm{GC}\left(\mathrm{c}^{\prime}\right)$ recorded in a $0.1 \mathrm{M} \mathrm{NaOH}$ solution (dashed lines) and that containing $0.1 \mathrm{M}$ glucose (solid lines) at a scan rate of $50 \mathrm{mV} \mathrm{s}^{-1}$ at $25^{\circ} \mathrm{C}$ (coloured online) 
are different and differ in the magnitude pointing to the fact that the surface of AuNPs synthesized by the use of halide additive is unequally active for the electro-oxidation of glucose and glucose intermediate species at the AuNPs $\mathrm{KCl}_{\mathrm{KC}} / \mathrm{C} 1 / \mathrm{GC}, \mathrm{AuNP}_{\mathrm{KBr}} /$ C1/GC, $\mathrm{AuNPs}_{\mathrm{KI}} / \mathrm{C} 1 / \mathrm{GC}$ or $\mathrm{AuNPs}_{\mathrm{KCl}} / \mathrm{C} 2 / \mathrm{GC}$ and $\mathrm{AuNP}_{\mathrm{KBr}} / \mathrm{C} 2 / \mathrm{GC}, \mathrm{AuNPs}_{\mathrm{KI}} / \mathrm{C} 2 / \mathrm{GC}$ catalysts (Fig. 6). Possibly, the use of different halide ions in the synthesis of the catalysts promotes the development of different specific crystallographic planes, since halide ions are well known to adsorb strongly on metallic surfaces, and thus, to affect the corresponding surface energies. Furthermore, the determined current density values also depend on the reducing agent used. It should be noted that regardless the reducing agent used, glucose electrooxidation currents generated on all the composites prepared in the presence of halide additive are higher as compared to those prepared in the absence of halides. Summarized positive-potential going scans recorded on the investigated composites are presented in Fig. 7a, b. They show that the availability of halide additive in the reaction mixture for the synthesis of the composites results not only in the increased glucose electro-oxidation current density values on the prepared composites, but also on the glucose electro-oxidation potential shift to the direction of more negative potential values as compared to those characteristics on the composites prepared without a halide additive. Almost in all cases, both current peak values $j_{\mathrm{pA} 1}$ and $j_{\mathrm{pA} 2}$ are higher on the AuNPs $\mathrm{KCl}_{\mathrm{KC}} / \mathrm{C} 2 / \mathrm{GC}$ and $\mathrm{AuNPS}_{\mathrm{KBr}} / \mathrm{C} 2 /$ $\mathrm{GC}$ catalysts when the complex mixture of glucose and ascorbic acid was used as a reducing agent in

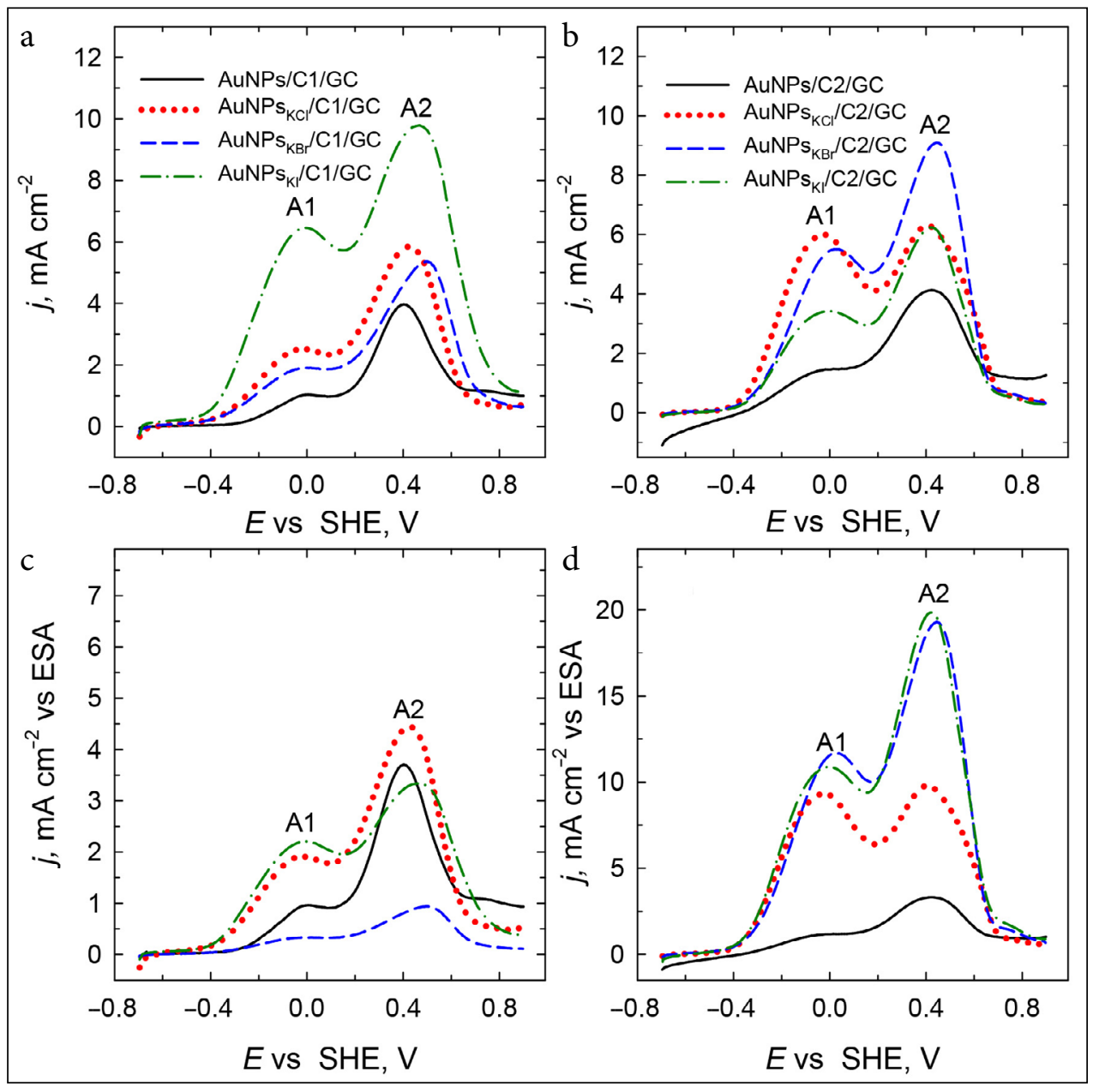

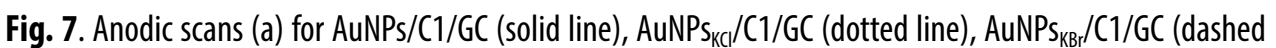
line), AuNPS $/ S_{K} / C 1 / G C$ (dash-dotted line) and (b) for AuNPs/C2/GC (solid line), AuNPS $S_{K C l} / C 2 / G C$ (dotted line), AuNPS $_{\mathrm{KBr}} / \mathrm{C} 2 / \mathrm{GC}$ (dashed line), AuNPS $/ \mathrm{C} 2 / \mathrm{GC}$ (dash-dotted line) recorded in a $0.1 \mathrm{M} \mathrm{NaOH}$ and $0.1 \mathrm{M} \mathrm{glucose}$ solution at a scan rate of $50 \mathrm{mV} \mathrm{s}^{-1}$ at $25^{\circ} \mathrm{C}(\mathrm{c}, \mathrm{d})$. Current density values normalized by the ESAs for each catalyst (coloured online) 
the presence of halide ions for the preparation of the catalysts as compared with those on the catalysts prepared by using the sodium citrate as a reducing agent in the presence of $\mathrm{Cl}^{-}$and $\mathrm{Br}^{-}$ions. Current peak values $j_{\mathrm{pA} 1}$ and $j_{\mathrm{pA} 2}$ are ca. 2.39 and 1.078 , and ca. 2.88 and 1.72 , respectively, times higher at the AuNPs $\mathrm{KCl} / \mathrm{C} 2 / \mathrm{GC}$ and $\mathrm{AuNPS}_{\mathrm{KBr}} / \mathrm{C} 2 /$ GC catalysts (Fig. $7 b$ ) when compared to those at $\mathrm{AuNPs}_{\mathrm{KCl}} / \mathrm{C} 1 / \mathrm{GC}$ and $\mathrm{AuNPs}_{\mathrm{KBr}} / \mathrm{Cl} / \mathrm{GC}$ (Fig. 7a), respectively. Meanwhile, an opposite influence on the glucose electro-oxidation current value is observed for the employment of KI additive. About 1.89 and 1.57 times higher current density values at anodic peaks $\mathbf{A 1}$ and $\mathbf{A 2}$, respectively, are generated for the $\mathrm{AuNPs}_{\mathrm{KI}} / \mathrm{C} 1 / \mathrm{GC}$ catalyst when sodium citrate was used as a reducing agent for the catalyst synthesis as compared to those for the AuNPs $\mathrm{KI}_{\mathrm{KI}} /$ C2/GC catalyst. Such behaviour of the AuNPs $/$ C1/GC catalyst can be explained by the development of the special architecture of aggregated AuNPs that formed a spatial network structure as is clearly seen in the FESEM image in Fig. 2c. This catalyst exhibits a high electrocatalytic activity for the electro-oxidation of glucose mainly due to the proper distribution of AuNPs over the carbon surface, which provides a fast electron transfer rate and a short diffusion path for a fuel molecule, and therefore, increases catalyst utilization.

In order to evaluate the electrocatalytic activity of the prepared composites between each other for the electro-oxidation of glucose, the obtained current density values were normalized with the respect to the ESAs for each catalyst and are given in

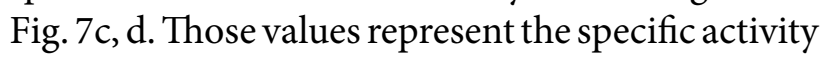

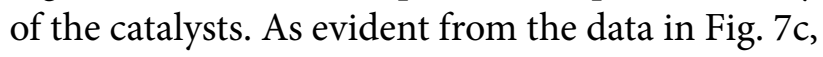
ca. 2 times higher current density values of peak $\mathbf{A} \mathbf{1}$ are recorded on AuNPs KCI $_{\text {C }} / \mathrm{Cl} / \mathrm{GC}$ and $\mathrm{AuNPs}_{\mathrm{KI}} /$ C1/GC as compared to those on AuNPs/C1/GC when the sodium citrate was used for the synthesis of those composites. Meanwhile, when the complex mixture of glucose and ascorbic acid was employed for the preparation of the composites, the current density values of anodic peak $\mathbf{A} \mathbf{1}$ are significantly higher on the $\mathrm{AuNP}_{\mathrm{KCl}} / \mathrm{C} 2 / \mathrm{GC}, \mathrm{AuNP}_{\mathrm{KBr}} / \mathrm{C} 2 / \mathrm{GC}$ and $\mathrm{AuNPs}_{\mathrm{KI}} / \mathrm{C} 2 / \mathrm{GC}$ catalysts as compared to those on AuNPs/C2/GC (Fig. 7d). Current density values of peaks $\mathbf{A} \mathbf{1}$ and $\mathbf{A 2}$ are ca. 7.86, 9.84 and 9.13, and 2.95, 5.79 and 5.98, respectively, times greater at the $\mathrm{AuNPs}_{\mathrm{KCl}} / \mathrm{C} 2 / \mathrm{GC}, \mathrm{AuNPs}_{\mathrm{KBr}} / \mathrm{C} 2 / \mathrm{GC}$ and $\mathrm{AuNPs}_{\mathrm{KI}} / \mathrm{C} 2 / \mathrm{GC}$ catalysts than those at AuNPs/C2/
GC (Fig. 7d). Meanwhile, the highest specific activity values under both anodic peaks $\mathbf{A} \mathbf{1}$ and $\mathbf{A} \mathbf{2}$ are shown by the composites, prepared by employing the complex mixture of glucose and ascorbic acid as a reducing agent. The presence of halide additive in the reaction mixture results in ca. 3 or even ca. 10 times increased specific activities under anodic peaks $\mathbf{A} 1$ and ca. 5 or even ca. 7 times increased specific activities under anodic peaks A2 (Fig. Ad) as compared to values determined on the analogous catalysts prepared by the help of sodium citrate coupled with $\mathrm{Cl}^{-}, \mathrm{Br}^{-}$and $\mathrm{I}^{-}$ions (Fig. $7 \mathrm{c}$ ).

\section{CONCLUSIONS}

In summary, the electro-oxidation of glucose has been examined in an alkaline medium using the carbon supported AuNPs composites prepared by the use of different reducing agents, such as sodium citrate or the complex mixture of glucose and ascorbic acid in the presence of small amounts of halide ions $\left(\mathrm{I}^{-}, \mathrm{Br}^{-}, \mathrm{Cl}^{-}\right)$. The electrochemical measurements demonstrate the enhanced electrocatalytic performance of the carbon supported AuNPs composites for the electro-oxidation of glucose prepared by the help of different reducing agents coupled with different halide ions as compared to those synthesized by the use of a reducing agent alone. It has been determined that the use of halide ions allows the preparation of catalysts with different AuNPs size ranging from 19 to $47 \mathrm{~nm}$. The special architecture of aggregated AuNPs that have a spatial network structure has been developed in the case when the KI additive and sodium citrate as a reducing agent were used for the preparation of the catalyst. This catalyst shows the highest mass activity for the direct electrooxidation of glucose as compared to other investigated composites. It was found that the employment of halide additives for the synthesis of the catalysts also allows the increase of the Au loading in the catalyst composition. The presence of $\mathrm{KCl}, \mathrm{KBr}$ or $\mathrm{KI}$ additive in the reaction mixture for the synthesis of the catalysts results in not only the increased glucose electro-oxidation current density values, but also shifts the glucose electro-oxidation potential to more negative potential values as compared to those characteristics on the prepared composites without halide additive. This demonstrates the improved electrocatalytic activity of the carbon supported AuNPs composites prepared in the presence of $\mathrm{KCl}$, 
$\mathrm{KBr}$ or $\mathrm{KI}$ additive for the electro-oxidation of glucose in an alkaline medium.

Received 2 September 2020 Accepted 15 September 2020

\section{References}

1. C. Louis, O. Pluchery, Gold Nanoparticles for Physics, Chemistry and Biology, Imperial College Press, London (2012).

2. D. Holec, P. Dumitraschkewitz, D. Vollath, et al., Nanomaterials, 10, 484 (2020).

3. V. Ramalingam, Adv. Colloid Interface Sci., 271, 101989 (2019).

4. R. J. White, R. Luque, V. L. Budarin, et al., Methods Appl. Chem. Soc. Rev., 38, 481 (2009).

5. Y. D. Han, Y. M. Park, H. J. Chun, et al., Sens. Actuators B, 220, 233 (2015).

6. P. M. Anjana, M. R. Bindhu, R. B. Rakhi, Mater. Sci. Energy Technol., 2, 389 (2019).

7. G. J. Hutchings, ACS Cent. Sci., 4, 1095 (2018).

8. A. Alshammari, V. N. Kalevaru, in: N. K. Mishra (ed.), Catalytic Application of Nano-Gold Catalysts, IntechOpen, London (2016).

9. Y. Zhou, C. Jin, Y. Li, et al., Nano Today, 20, 101 (2018).

10. N. Elahi, M. Kamali, M. H. Baghersad, Talanta, 184, 537 (2018).

11. H.-H. Jeong, E. Choi, E. Elliscd, et al., J. Mater. Chem. B., 7, 3480 (2019).

12. P. Jiang, Y. Wang, L. Zhao, et al., Nanomaterials, 8, 977 (2018).

13. S. Farid, R. Kuljic, S. Poduri, et al., Superlattices Microstruct., 118, 1 (2018).

14. G. Vinci, M. Rapa, Bioeng., 6, 10 (2019).

15. D. Chakraborty, M. Venkatesan, K. R. Ethiraj, et al., Mater. Chem. Phys., 239, 122295 (2020).

16. S. Cai, X. Xiao, X. Ye, et al., Mater. Lett., 166, 51 (2016).

17. Q. Wangn, F. Min, J. Zhu, Mater. Lett., 91, 9 (2013).

18. R. Omar, A. En Naciri, S. Jradi, et al., J. Mater. Chem., C., 5, 10813 (2017).

19. C.-J. Huang, Y.-H. Wang, P.-H. Chiu, et al., Mater. Lett., 60, 1896 (2006).

20. Z. Guo, X. Fan, L. Liu, et al., J. Colloid Interface Sci., 348, 29 (2010).

21. M. Alloisio, M. I. Martinez-Espinoza, G. Dellepiane, et al., Mater. Chem. Phys., 242, 122472 (2020).

22. T. Xiao, J. Huang, D. Wang, et al., Talanta, 206, 120210 (2020).

23. K. Kalimuthu, B. S. Cha, S. Kim, et al., Microchem. J., 152, 104296 (2020).

24. Y. Kumari, G. Kaur, R. Kumar, et al., Adv. Colloid Interface Sci., 274, 102037 (2019).

25. Y. Ni, C. Ka, J. Xu, et al., Superlattices Microstruct., 114, 124 (2018).
26. V. Pareek, A. Bhargava, R. Gupta, et al., Adv. Sci. Eng. Med., 9, 528 (2017).

27. C. D. De Souza, B. R. Nogueira, M. Elisa, et al., J. Alloys Compd., 798, 714 (2019).

28. G. Darabdhara, M. R. Das, S. P. Singh, et al., Adv. Colloid Interface Sci., 271, 101991 (2019).

29. S. Koeppl, N. Ghielmetti, W. Caseri, et al., J. Nanopart. Res., 15, 1471 (2013).

30. K. I. Requejo, A. V. Liopo, P. J. Derry, et al., Langmuir, 33, 12681 (2017).

31. T.-H. Yang, Y. Shi, A. Janssen, et al., Angew. Chem. Int. Ed., doi: 10.1002/anie.201911135 (2019).

32. P. Zhao, N. Li, D. Astruc, Coord. Chem. Rev., 257, 638 (2013).

33. E. Agunloye, A. Gavriilidis, L. Mazzei, Chem. Eng. Sci., 173, 275 (2017).

34. L. Shi, E. Buhler, F. Boue, et al., J. Colloid Interface Sci., 492, 191 (2017).

35. E. Agunloye, L. Panariello, A. Gavriilidis, Chem. Eng. Sci., 191, 318 (2018).

36. F. Takahashi, N. Yamamoto, M. Todoriki, et al., Talanta, 188, 651 (2018).

37. S. Bandyopadhyay, G. Singh, W. R. Glomm, Mater. Today Chem., 3, 1 (2017).

38. P. Priecel, H. A. Salami, R. H. Padilla, et al., Chin. J. Catal., 37, 1619 (2016).

39. J. S. DuChene, W. Niu, J. M. Abendroth, et al., Chem. Mater., 25, 1392 (2013).

40. C. Xue, Q. Li (ed.), Anisotropic Nanomaterials: Preparation, Properties, and Applications, Springer International Publishing, Cham (2015).

41. M. R. Langille, M. L. Personick, J. Zhang, et al., J. Am. Chem. Soc., 134, 14542 (2012).

42. S. E. Lohse, N. D. Burrows, L. Scarabelli, et al., Chem. Mater., 26, 34 (2014).

43. N. Almora-Barrios, G. Novell-Leruth, P. Whiting, et al., Nano Lett., 14, 871 (2014).

44. T. H. Ha, H.-J. Koo, B. H. Chung, J. Phys. Chem. C, 111, 1123 (2007).

45. N. Garg, C. Scholl, A. Mohanty, et al., Langmuir, 26, 10271 (2010).

46. D. K. Smith, N. R. Miller, B. A. Korgel, Langmuir, 25, 9518 (2009).

47. B. T. Sneed, M. C. Golden, Y. Liu, et al., Surf. Sci., 648, 307 (2016).

48. A. S. Alshammari, Catalysts, 9, 402, (2019).

49. Y. Zhang, Y. Song, J. Zhao, et al., J. Alloys Compd., 822, 153322 (2020).

50. K. S. Bhavani, T. Anusha, P. K. Brahman, Int. J. Hydrogen Energy, 44, 25863 (2019).

51. H. Zhang, Y. Luo, D. Chen, et al., Green Energy Environ., doi: 10.1016/j.gee.2020.03.007 (2020) (in press).

52. W. Hu, D. Li, Y. Yang, et al., J. Catal., 357, 108 (2018).

53. Z. Zheng, T. Tachikawa, T. Majima, J. Am. Chem. Soc., 137, 948 (2015).

54. T.-F. Chu, R. Rajendran, I. Kuznetsova, et al., J. Power Sources, 453, 227844 (2020). 
55. S. Hebié, Y. Holade, K. Maximova, et al., ACS Catal., 5, 6489 (2015).

56. M. Pasta, R. Ruffo, E. Falletta, et al., Gold Bull., 43, 57 (2010).

57. A. Brouzgou, P. Tsiakaras, Top. Catal., 58, 1311 (2015).

58. S. Hebié, K. B. Kokoh, K. Servat, et al., Gold Bull., 46, 3118 (2013).

59. H. Angerstein-Kozlowska, B. E. Conway, A. Hamelin, et al., Electrochim. Acta, 31, 1051 (1986).

60. M. Pasta, F. La Mantia, Y. Cui, Electrochim. Acta, 55, 5561 (2010).

61. N. Arjona, G. Trejo, J. Ledesma-García, et al., RSC $A d v .$, 6, 15630 (2016).

62. N. Arjona, M. Guerra-Balcázar, G. Trejo, et al., New J. Chem., 36, 2555 (2012).

63. G. C. A. Ferreira, T. W. Napporn, K. B. Kokoh, et al., J. Electrochem. Soc., 164(9), H603 (2017).

64. R. A. Escalona-Villalpando, M. P. Gurrola, G. Trejo, et al., J. Electroanal. Chem., 816, 92 (2018).

65. A. Brouzgou, P. Tsiakaras, Top. Catal., 58, 1311 (2015).

66. R. S. Nicholson, I. Shain, Anal. Chem., 36, 706 (1964).

67. M. Y. Elahi, H. Heli, S. Z. Bathaie, et al., J. Solid State Electrochem., 11, 273 (2007).
Daina Upskuvienė, Dijana Šimkūnaitè,

Jūratė Vaičiūnienė, Virginija Kepenienè, Algirdas Selskis,

Loreta Tamašauskaitè-Tamašiūnaitè, Eugenijus Norkus

GLIUKOZE்S ELEKTROOKSIDACIJOS ANT

AUKSO NANODALELIŲ / ANGLIES KOMPOZITŲ, SUFORMUOTŲ NAUDOJANT HALOGENIDŲ PRIEDUS, TYRIMAS

Santrauka

Darbe $\mathrm{Au}$ nanodalelių/anglies kompozitai (AuNPs/C) buvo gauti naudojant du skirtingus reduktorius: trinatrio citratą ir gliukozès bei askorbo rūgšties mišinị, esant nedideliam kiekiui skirtingų halogenido jonų $\left(\mathrm{Cl}^{-}, \mathrm{Br}^{-}, \mathrm{I}^{-}\right)$. Gautų AuNPs/C kompozitų morfologija ir sudètis buvo apibūdinti naudojant skenuojančiąą elektroninę mikroskopiją ir indukuotos plazmos optinès emisijos spektroskopiją, o jų elektrokatalizinis aktyvumas buvo įvertintas gliukozès elektrooksidacijai šarminèje terpejje naudojant ciklinę voltamperometriją.

Nustatyta, kad ženkliai didesniu elektrokataliziniu aktyvumu gliukozès elektrooksidacijos reakcijai šarmineje terpejje pasižymi AuNPs/C kompozitai, susintetinti naudojant skirtingus reduktorius ir halogenidų priedus, palyginti su AuNPs/C kompozitais, kurie buvo susintetinti naudojant tik reduktorius be halogenidų priedų. Daug didesnès gliukozès elektrooksidacijos srovès tankio vertès buvo išmatuotos ant AuNPs/C kompozitų, susintetintu naudojant halogenidu priedus $(\mathrm{KCl}, \mathrm{KBr}, \mathrm{KI})$, palyginti su kompozitais, susintetintais nenaudojant halogenidų. Be to, gliukozès oksidacija ant šių katalizatorių vyksta esant labiau neigiamoms elektrodo potencialo vertèms nei ant AuNPs/C katalizatorių, susintetintų nenaudojant halogenidų priedų. Tai rodo padidintą šių katalizatorių aktyvumą gliukozès elektrooksidacijos reakcijai. 